\title{
Undergraduate Program in Network Engineering and Security - A Feasibility Study
}

\author{
Fahed Awad \\ Department of Network Engineering and Security, Jordan University of Science and Technology, Irbid, Jordan \\ Email: fhawad@just.edu.jo \\ Omar Banimelhem \\ Department of Network Engineering and Security, Jordan University of Science and Technology, Irbid, Jordan \\ Email: omelhem@just.edu.jo \\ Eyad Taqieddin \\ Department of Network Engineering and Security, Jordan University of Science and Technology, Irbid, Jordan \\ Email: eyadtaq@just.edu.jo \\ Raed Bani-Hani \\ Department of Network Engineering and Security, Jordan University of Science and Technology, Irbid, Jordan \\ Email: rbanihani@just.edu.jo
}

\begin{abstract}
In this article, a feasibility study for initiating a new undergraduate program in network engineering and security is presented. The study was based on surveying and analyzing the current and projected future market demand for specialized network engineering graduates. The results of the study concluded that the demand for such a specialty in the work place is rapidly growing as the networking and telecommunication technologies are becoming essential and integral parts of about any organization around the world. As a result of the study, a pioneering program of network engineering and security was established at the Jordan University of Science and Technology.
\end{abstract}

Index Terms-Undergraduate Program, Feasibility, Network, Engineering, Job Market,Security.

\section{INTRODUCTION}

In the past few years, the importance of the Internet and secure communication in peoples' lives has been increasing rapidly whether at home, at work, or even on the road. People use their cell phones for voice communication as well as for short messaging and Internet access. They also use their personal computers for Internet access as well as for voice communication. The cost of using these technologies has dropped down considerably due to competition and mass production of electronic devices, which led torelatively large penetration ratios of such technologies in all aspects of life, especially in the work place. Therefore, the need for a network and security specialist, whether a network engineer, administrator, programmer, or support staff, in the work place has become increasingly mandatory.

At the Department of Computer Engineering, Jordan University of Science and Technology (JUST), several undergraduate courses that are related to the computer networks and security fields are offered ranging from mandatory courses, such as Data Communications and
Computer Networks, to elective advanced courses such as Internetworking, Network Security, and Wireless Networks; in addition to some graduate-level courses such as Advanced Networks and Advanced Network Security.

In the past few years, it has become very clear that the students' demand (whether graduate or undergraduate) for computer networks and security courses and training is increasing as result of the increasing demand in the market place for such knowledge.

Based on the feedback from the market place, it was observed that although our graduates are strongly competing for computer networks related position and excelling in such positions, there is still a demand for more in-depth courses and hands-on training related to the computer networks and security fields of study.

As a result, the administration of the College of Computer and Information Technology (CIT) has initiated this study with the objective of investigating the academic and technical feasibility of starting a standalone program for network engineering and security.

The purpose of this document is to provide information on the feasibility of initiating a new program of network engineering and security within the CIT at JUST.

The rest of this document is organized as follows: Section II describes the methodology used for the study; Section III reviews the similar existing programs locally, regionally, and internationally.A description of the potentials of the proposed program is given in Section IV followed by the conclusions and the recommendations of the study in Section V.

\section{The Methodology OF THE STUdy}

This study was performed based on research and analysis in several directions, which are: 
1. Research and review similar existing network engineering programs locally, regionally, and internationally in order to have an insight into others' experiences in offering such programs. This includes, but not limited to, the academic as well as the organizational aspects of the existing program such as:

a) The type of degree offered. For example, bachelor in network engineering, master of computer networks and security, etc.

b) The organizational aspects of the existing programs. For example, whether they are standalone programs or tracks within other programs.

2. Collect and analyze information from JUST computer engineering graduates in the workplace, both bachelor or master degree holders, regarding the following:

a) The focus field(s) of study when they were students.

b) The career fields they encountered and occupied after they graduated.

c) The locations (i.e.; cities and countries) they worked at as professionals after they graduated.

d) The anticipated job market needs and trends for the computer engineering fields from their own experiences.

3. Collect and categorize information regarding the computer engineering fields of research that past and current graduate students in the computer engineering department are tackling. This provides another indicator of peoples' focus field(s) of study and the choice of the field of specialty in the work place.

4. Collect and analyze data regarding the professional job markets' current needs and the anticipated future trends with regards to computer engineering fields. This was performed in two directions:

a) Reviewing published job market studies conducted by recruiting companies or computer technology and training providers.

b) Collecting examples of currently available job positions in the different computer engineering fields via major regional recruiting companies' search engines.

\section{EXISTING NETWORK ENGINEERING AND SECURITY PROGRAMS}

The idea of initiating a standalone department of network engineering and security has caused a hot debate among the faculty members of the computer engineering department. One major concern was whether similar programs exist in the academic world and how risky this step would be. Thus, it was quite important to find out whether other schools have done this before in order to learn from their experiences.

Utilizing the Internet search engines provided this study with many universities and colleges around the world that have similar programs and offer different degrees in network engineering and security. These programs were classified into three categories:

1. Standalone bachelor programs (see Table 1).

2. Concentration areas or tracks within other programs (see Table 2).

3. Master programs (seeTable 3).

Table 1: Existing standalone bachelor degree programs

\begin{tabular}{|c|c|c|}
\hline Department & $\begin{array}{l}\text { University/ } \\
\text { College }\end{array}$ & Country \\
\hline $\begin{array}{c}\text { Department of } \\
\text { Computer Network } \\
\text { Systems [1] }\end{array}$ & $\begin{array}{l}\text { Applied } \\
\text { Science } \\
\text { University }\end{array}$ & Jordan \\
\hline $\begin{array}{l}\text { The Department of } \\
\text { Computer \& Network } \\
\text { Engineering [2] }\end{array}$ & $\begin{array}{l}\text { L'Universit } \\
\text { éLibre de } \\
\text { Bruxelles }\end{array}$ & Belgium \\
\hline $\begin{array}{l}\text { Department of } \\
\text { Information and } \\
\text { Network } \\
\text { Engineering [3] }\end{array}$ & $\begin{array}{c}\text { Kurume } \\
\text { Institute of } \\
\text { Techno }\end{array}$ & Japan \\
\hline $\begin{array}{c}\text { Department of } \\
\text { Computer Science \& } \\
\text { Network } \\
\text { Engineering [4] }\end{array}$ & $\begin{array}{l}\text { Southern } \\
\text { Nazarene } \\
\text { University }\end{array}$ & USA \\
\hline $\begin{array}{c}\text { Department of } \\
\text { Computer Information } \\
\text { and Network } \\
\text { Engineering [5] }\end{array}$ & $\begin{array}{c}\text { Lunghwa } \\
\text { University } \\
\text { of Science } \\
\text { and } \\
\text { Technology }\end{array}$ & Taiwan \\
\hline $\begin{array}{c}\text { Computer and } \\
\text { Network } \\
\text { Engineering [6] }\end{array}$ & $\begin{array}{l}\text { Sheffield } \\
\text { Hallam } \\
\text { University }\end{array}$ & UK \\
\hline $\begin{array}{c}\text { Computer \& Network } \\
\text { Security [7] }\end{array}$ & $\begin{array}{l}\text { Wilmington } \\
\text { University. }\end{array}$ & USA \\
\hline $\begin{array}{c}\text { Network } \\
\text { Engineering [8] }\end{array}$ & FHKärnten & Austria \\
\hline $\begin{array}{c}\text { The Department of } \\
\text { Networking, Security, } \\
\text { and Systems } \\
\text { Administration [9] }\end{array}$ & $\begin{array}{c}\text { Rochester } \\
\text { Institute of } \\
\text { Technology }\end{array}$ & USA \\
\hline
\end{tabular}

Table 2: Existing programs as a track within a department

\begin{tabular}{|c|c|c|}
\hline Department & $\begin{array}{c}\text { University/ } \\
\text { College }\end{array}$ & Country \\
\hline Computer and & Purdue & USA \\
Information & University & \\
Technology & & \\
(Track in Network & & \\
Engineering & & \\
Technology) [10] & & \\
\hline
\end{tabular}

Table 3: Existing master programs worldwide

\begin{tabular}{|c|c|c|}
\hline $\begin{array}{c}\text { Name of the } \\
\text { program }\end{array}$ & $\begin{array}{c}\text { University/ } \\
\text { College }\end{array}$ & Country \\
\hline Master in Computer & University & USA \\
Engineering - & of & \\
Network & California, & \\
Engineering[11] & Santa Cruz & \\
\hline
\end{tabular}




\begin{tabular}{|c|c|c|}
\hline $\begin{array}{c}\text { MasterofEngineerin } \\
\text { gin } \\
\begin{array}{c}\text { Telecommunications } \\
{[12]}\end{array}\end{array}$ & $\begin{array}{c}\text { University } \\
\text { of Toronto }\end{array}$ & Canada \\
\hline $\begin{array}{c}\text { Master program in } \\
\text { Network } \\
\text { Engineering [13] }\end{array}$ & $\begin{array}{c}\text { RMIT } \\
\text { University }\end{array}$ & Australia \\
\hline $\begin{array}{c}\text { Master of Network } \\
\text { Engineering [14] }\end{array}$ & $\begin{array}{c}\text { Illinois } \\
\text { Institute of } \\
\text { Technology }\end{array}$ & USA \\
\hline $\begin{array}{c}\text { Master in Computer } \\
\text { Networking [15] }\end{array}$ & $\begin{array}{c}\text { North } \\
\text { Carolina } \\
\text { State } \\
\text { University }\end{array}$ & USA \\
\hline $\begin{array}{c}\text { Master of Science in } \\
\text { Security } \\
\text { Informatics [16] }\end{array}$ & $\begin{array}{c}\text { The Johns } \\
\text { Hopkins } \\
\text { University }\end{array}$ & USA \\
\hline $\begin{array}{c}\text { Master in Network } \\
\text { Management and } \\
\text { Security [17] }\end{array}$ & $\begin{array}{c}\text { Murdoch } \\
\text { University }\end{array}$ & Australia \\
\hline $\begin{array}{c}\text { Master of } \\
\text { Information Systems } \\
\text { Security [18] }\end{array}$ & $\begin{array}{c}\text { Charles } \\
\text { Sturt } \\
\text { University }\end{array}$ & Australia \\
\hline
\end{tabular}

Based on the tables above, following is a summary of the findings:

1. Locally, only one program is offered in the field of computer networks at the Applied Science University, Amman, Jordan. This program prepares the students to work in the field of computer networks after completing 130 credit hours. However, this program concentrates mostly on the programming aspect of computer networks rather than the engineering aspect [1].

2. Regionally, no such programs were found.

3. Internationally, it was found that a number of universities around the world have standalone programs in computer network engineering and/or in network security. Three of these universities are in USA. However, it is clearly noticed that these universities are not among the top ranked schools in engineering in USA.

4. Some universities developed master programs in network engineering or network security within other departments such as electrical and computer engineering, information technology, or computer science

\section{The Potentials of the Proposed Program}

In this section, the potentials of the proposed program are presented and discussed. The information provided in this section is based on a survey [19] that was conducted on computer engineering graduates who are either occupying professional positions or pursuing higher academic degrees around the world. The following sections discuss the survey and its outcomes.

\section{A. The Survey of the Computer Engineering Graduates}

To conduct the survey, a web page with a number of questions was published and email messages were sent to a few hundreds of computer engineering graduates urging them to participate in the survey and provide their feedback and to spread the word to others.

About one hundred and thirty graduates from a wide range of locations, backgrounds, and graduation years have participated in the survey up to the time this document was written. Among those, $86 \%$ were males and $14 \%$ were females.

Figure 1 depicts the distribution of the participants' graduation year. It is noticed that $80 \%$ the participants graduated within the last three years whereas about 5\% graduated before year 2000 .

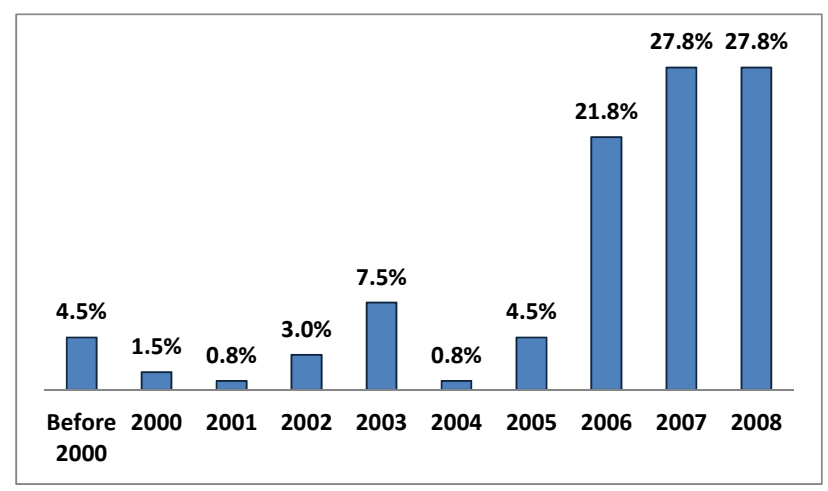

Figure 1: Distribution of the participants' graduation year

Figure 2 depicts the distribution of the participants' work locations. It is noticed that about $70 \%$ of them work in Jordan, whereas $30 \%$ of them work around the world.

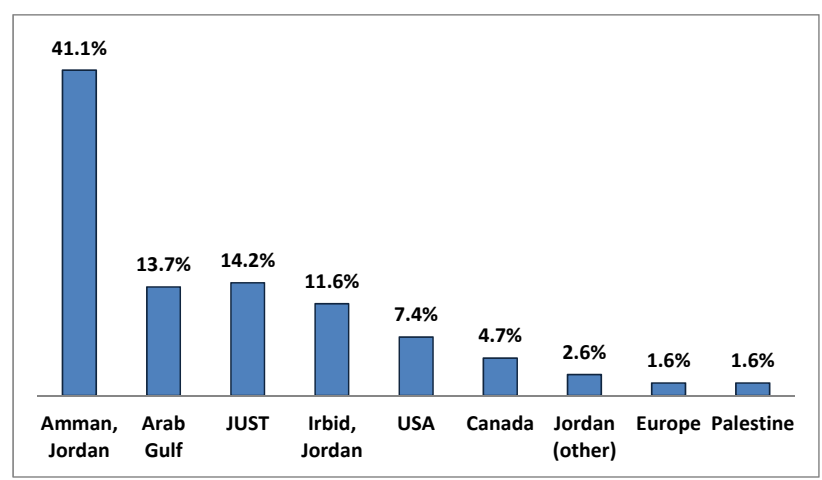

Figure 2: Distribution of participants' work locations

Figure 3 depicts the distribution of the participants' working years of experience. It is noticed that about $90 \%$ of the participant have work experiences of three years or less. This is obvious since most of them graduated within the past three years as mentioned before.

\section{B. Computer Engineering Focus Fields of Study}

Like most computer engineering departments, a number of senior-level courses are offered in three main fields: computer networks, software systems, and hardware systems. The student, after taking the basic courses, has the chance to focus on a field of interest and take more courses in such a field. 


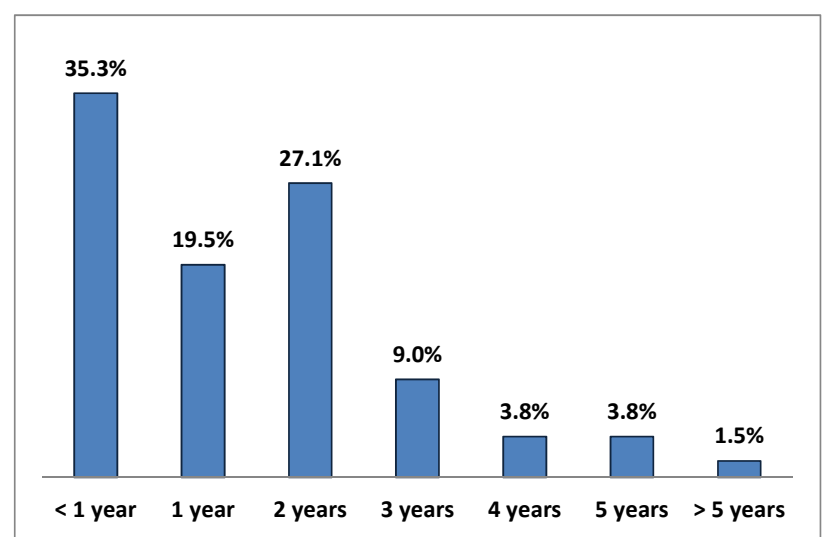

Figure 3: Distribution of participants' work experience

In the survey, the graduates were asked about their focus field(s) of interest during their study. Figure 4 depicts the distribution of graduates' fields of interest. It is obvious that the most popular field was the computer networks field followed by the software systems field. Then the graduates were asked about the types of job positions they occupied during their career in order to find the correlation with their focus field of interest during their study. Figure 5 depicts that there is indeed a very good correlation. This indicates that the students were mainly aware of the job market needs and trends when they chose their focus fields of study. It should be also noted that only $3.6 \%$ of the participants have never been employed, even though most of them have graduated within the last three years, as mentioned before. This is a good indicator that our graduates are well-accepted in the work place even as fresh graduates (see Figure 3 above).

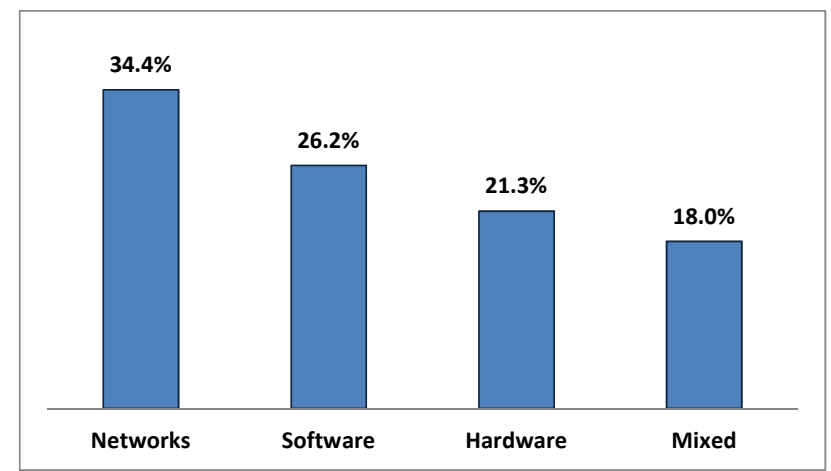

Figure 4: Computer engineering focus fields of interest

\section{Computer Engineering Focus Fields of Research}

Another survey was conducted regarding the research fields of interests among the graduate students in the computer engineering department. This was performed by categorizing the research fields of the master dissertations.

Different research topics fall within the areas of focus of the network engineering and security department. Figure 6 shows the distribution of research topics broken down into several categories. Note that some theses fell into different categories and thus were counted more than once for each respective category.

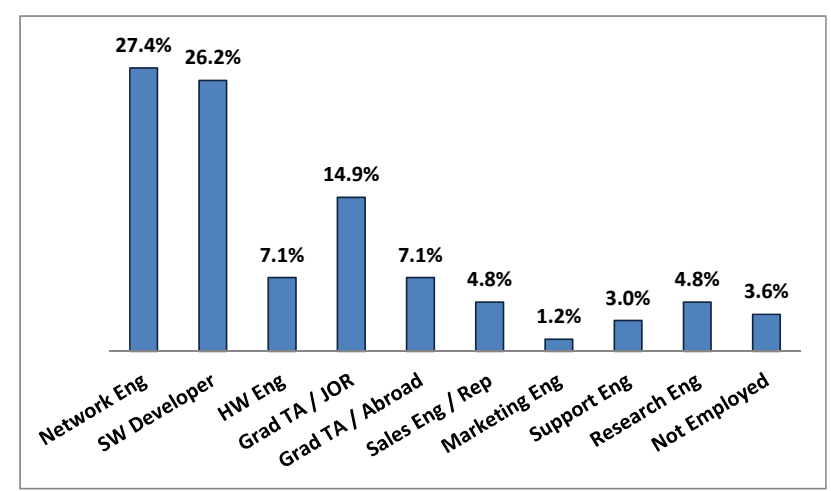

Figure 5: Computer engineering career fields

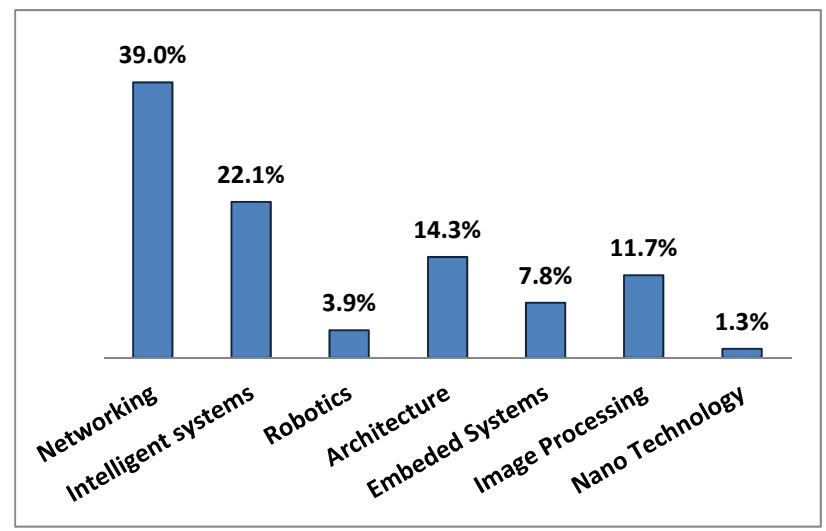

Figure 6: Distribution of graduate research fields tackled

The area of computer networks has received the highest focus of research with the next area of interest being the Intelligent Systems.

Figure 7 shows the various categories of research conducted within the area of computer networks. Again, some theses may have covered more than one topic and thus were included in more than one category. Wireless networks category ranked number one among the topics of interest followed by Quality of Service, Network Security, and Network Routing, respectively.

The observations above indicate along with the ever increasing market demand the necessity to sustain and improve the level of research being done by qualified network engineers who have a solid theoretical and practical background.

\section{Job Market Analysis}

In this section, we provide a best-effort analysis for market demand and future need for specialists in the networking and security area. This was conducted via three different approaches:

1. Querying the graduates via the survey for their vision of the job market potentials from their experiences in the work places.

2. Collecting examples of currently available job positions in the different computer engineering fields via major regional recruiting companies' search engines.

3. Reviewing published job market studies conducted by recruiting companies or computer technology and training providers. 


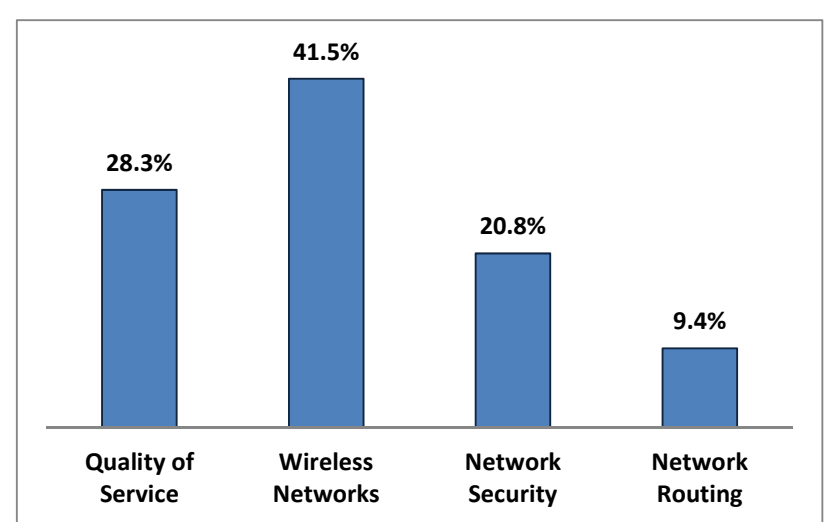

Figure 7: Distribution of graduate research tackled in the networking field

\section{E. The Graduates' Feedback}

We asked the graduates for their opinions regarding the job market potentials for the computer engineering fields of study based on their experiences in the work places for the current time and the near future. That is, which are the most wanted fields by the job market. Figure 8 shows the results. It is obvious that the computer networks field has the highest potential and is the most wanted computer engineering field in the job market. Moreover, Figure 9 shows the breakdown of the most wanted specialty within the computer networks field. This gives us an insight on which tracks of computer networks need to be focused on the most.

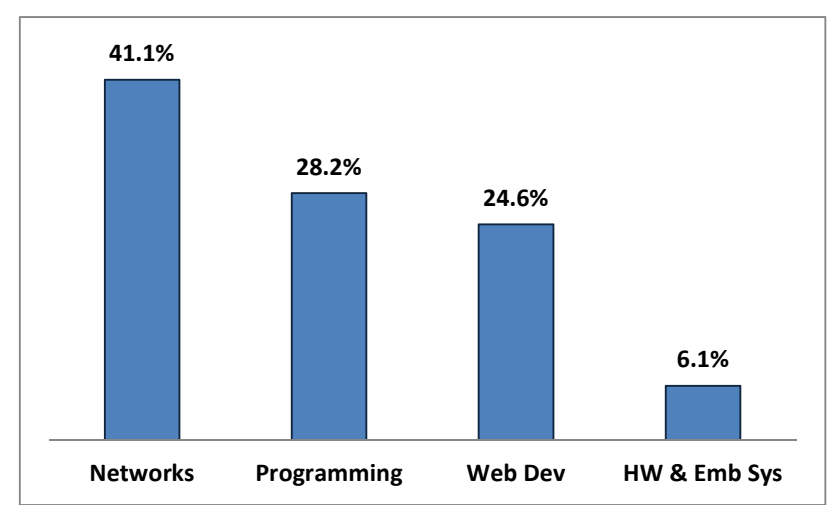

Figure 8: Job market potentials for computer engineering fields of study

\section{F. Examples of Current Job Market Demand}

To get a sense of the market demands on the regional level, a leading online career-service provider in the region, Bayt.com [20], was contacted for assistance.

The job-search service of that company's website was used to search for jobs based on areas and to observe the current demand for careers related to networking and security fields. Out of 570 jobs available at that time inthe fields of information technology, computer hardware, computer software, and telecommunications, it was found that about 120 jobs were purely in networking and security fields. This is almost $21.5 \%$ of the job market. In addition, some of the jobs might require some knowledge in the networking and security area such as sales engineer, IT consultant, system administrator, and programmer. Such jobs are not of the 120 jobs mentioned above. By combining the jobs that are networking and security related with others closely related jobs the number will be much higher and the market demand for the graduates from a networking and security program may be expected to be high in the regional market.

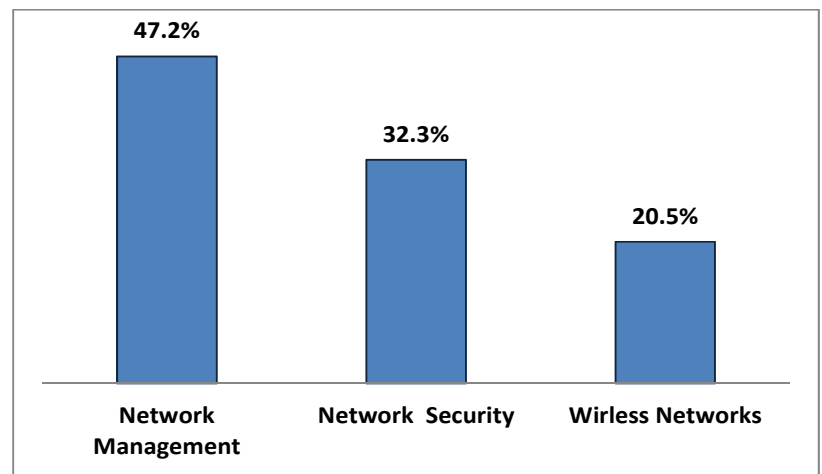

Figure 9: Job market potentials for computer networking fields of study

\section{J. Published Job Market Studies}

A commissioned study conducted by Forrester Consulting on behalf of Cisco [21] showed some promising expectations for the market in the coming years. Figure 10 shows the current and projected expectations of hiring among 1500 managers in the computer networks field. The data shows an increasing trend of hiring dedicated professionals for 5 different fields of computer networks. Within the coming five years, $80 \%$ of the companies will have dedicated people for the tasks of network security. $69 \%$ of the reporting companies will dedicate positions for both fields of voice communication and network operations. The number is expected to drop to $66 \%$ in the field of wireless networks. Finally, $61 \%$ of the companies expect to have professionals working solely as remote office and teleworkers.

The report claims that: "As the sophistication of the network increases, however, the skills requirements for network professionals will also increase. Traditional positions within the network - such as network architects, engineers, and administrators - require employees with more specialized skills and greater levels of experience. At the same time, new job skills related to security, voice, wireless, and remote office work are becoming critical to the functionality of the network. What should IT managers do? They need to hire, train, and ramp dedicated professionals. In this rapidly changing network environment, network education, skills assessment tools, and training and certification programs are required."

From the report, more than half of the managers stressed the importance of having a university degree related to networks. Around a third of them emphasized the importance of having a more advanced degree such as Masters or Doctorate degrees. This highlights the need for a specialized program that focuses both on the theoretical background as well as the technical abilities of the future professionals. Figure 11 shows the breakdown of various needed qualifications levels. 


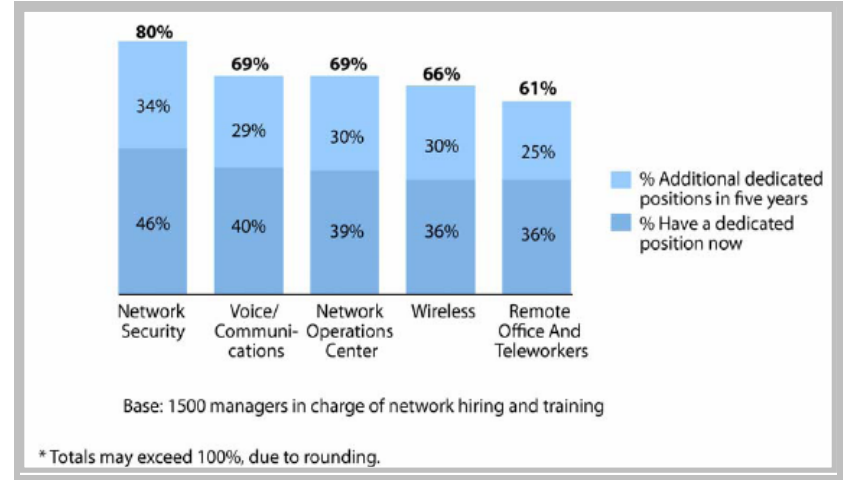

Figure 10: Current and projected hiring in the computer networks fields [21]

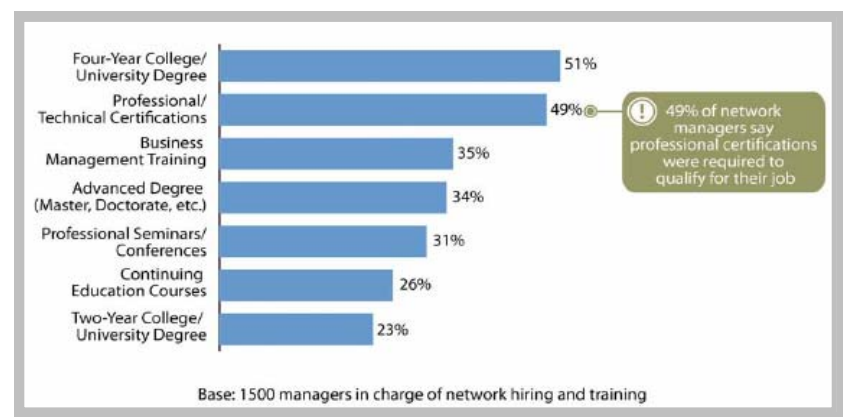

Figure 11: Needed qualifications for computer networks professionals [21]

\section{CONCLUSIONS}

The advances in technology which have been accompanied by the increasing growth in the telecommunication sector in different fields have made the need to prepare network and security professionals persons that are well-educated and well-trained a necessary issue. In addition, the terms such as "networking", "network engineer", and "network security specialist" are now frequently used in the telecommunication sector. Academic organizations such as universities should stand strongly to prepare highlyqualified engineers for this sector.

In this study, the demand for such specialty has been analyzed in three different directions: locally, regionally, and globally. Information, reports, published studies, and articles regarding market current status and future demand were searched in order to reach a good characterization and visualization of the market.

Locally, there is very little information about the market, of which most was based on personal experience. No official reports or studies that describe the current status or future demand of the local job market were available. Therefore, a survey has been conducted among 130 graduates of the department of Computer Engineering at JUST, of which the results have raised two important observations:

1. There is a high employment rate among the graduates of JUST. Only with very few respondents of the survey (about 4\%) reporting that they have never been employed.

2. There is a high tendency of employment in the field of computer networking, including network management, network security, and wireless networking.

Regionally, there is also very little information about the local market. Therefore, a simple Internet-based jobsearch was performed on the current regional demand for careers related to computer networking and security fields. The results showed that over $21 \%$ of the job market demand in the fields of information technology, computer hardware, computer software, and telecommunications, was in the computer networking and security field.

Globally, studies have stressed the importance of having a university degree related to computer networks. They also emphasized the importance of having a more advanced degree such as Masters or Doctorate degrees. The studies anticipate that within the coming five years, $80 \%$ of the companies will have dedicated people for the tasks of network security. $69 \%$ of the companies will dedicate positions for both fields of voice communication and network operations. The number is expected to drop to $66 \%$ in the field of wireless networks. Finally, $61 \%$ of the companies expect to have professionals working solely as remote office and teleworkers.

This highlights the need for a specialized program that focuses both on the theoretical background as well as the technical abilities of the future professionals.

\section{REFERENCES}

[1] Department of Computer Network Systems, Applied Science University, Jordan, $\quad$ http://www.aspu.edu.jo/ الكليات/علمالحاسوبوتكنولوجيا المعلومات/الاقفامالاكاديمية/نظمالثبكاتالحاسو بية/tabid/768/Default.aspx

[2] The Department of Computer \& Network Engineering, L'UniversitéLibre de Bruxelles, Belgium, http://cs.ulb.ac.be/membres

[3] Department of Information and Network Engineering, Kurume Institute of Techno, Japan, http://www.kurumeit.ac.jp/english/faculty/information.html

[4] Department of Computer Science \& Network Engineering, Southern Nazarene University, USA, http://www.snu.edu/department-of-computerscience-network-engineering

[5] Department of Computer Information and Network Engineering, Lunghwa University of Science and Technology,

Taiwan, http://english.moe.gov.tw/sp.asp?xdURL=./school /school 21 departments department.asp \&SchoolID $=1030$ $\&$ SchoolAcademyID $=96 \&$ AcademyDepartmentID $=78 \& \mathrm{ct}$ Node $=6571 \&$ href from $=\&$ eat subcategory $\mathrm{str}=\& \mathrm{mp}=103$ $\underline{0}$

[6] Computer and Network Engineering, Sheffield Hallam University,

UK, http://prospectus.shu.ac.uk/op_pglookup1.cfm?id_nu $\underline{\mathrm{m}=391}$

[7] Computer \& Network Security, Wilmington University., USA, http://www.wilmu.edu/itac/cns_about.aspx

[8] Network Engineering, FH Kärnten, Austria, http://www.fhkaernten.at/cms_eng/tel.htm

[9] The Department of Networking, Security, and Systems Administration, Rochester Institute of Technology, USA, http://www.nssa.rit.edu/?q=node/4 
[10] Computer and Information Technology, Purdue University, USA, http://www.tech.purdue.edu/Cit/academics/undergra duate/currareas/NET.cfm

[11] MS in Computer Engineering -- Network Engineering, University of California, Santa Cruz, USA, http://www.ce.ucsc.edu/node/22

[12] Master of Engineering in Telecommunications, University of Toronto, Canada, http://www.nal.utoronto.ca/met/

[13] Master program in Network Engineering, RMIT University, Australia, http://mams.rmit.edu.au/bbjleoskdn7i.pdf, http:/ /mams.rmit.edu.au/eolprogsummaries/mc165

[14] Master of Network Engineering, Illinois Institute of Technology,

USA, http://www.iit.edu/engineering/ece/programs/grad/m s ne.shtml

[15] Master in computer Networking, North Carolina State University, USA, http://networking.ncsu.edu/index.php

[16] Master of Science in Security Informatics, The Johns Hopkins

USA, http://web.jhu.edu/jhuisi/institute/index.htm

[17] Masters in Network Management and Security, Murdoch University,

Australia, http://intsec.murdoch.edu.au/mnms structure.ht $\underline{\mathrm{ml}}$

[18] Master of Information Systems Security, Charles Sturt University,

Australia, http://www.csu.edu.au/handbook/handbook05/p $\mathrm{g} / \mathrm{p} 5$ 12.html

[19] Alumni Survey. Jordan University of Science and Technology. http://www.just.edu.jo/ fhawad/cpefinall1/

[20] Bayt.com. http://www.bayt.com/

[21] Closing The IT Network Skills Gap, How managers can understand and prepare fornew networking skill requirements. Cambridge : Forrester Research Inc., June, 2008.https://learningnetwork.cisco.com/servlet/JiveServlet/ previewBody/2300-102-2-6266/Forrester/-

/Cisco/TLP/Fina/0060208.pdf

Fahed Awad received his B.S. degree in Electrical and Computer engineering from the Jordan University of Science and Technology (JUST), Irbid, Jordan in 1990 and his M.S. and Ph.D. degrees in Electrical and Computer Engineering from the University of Wisconsin Milwaukee (UWM) in 1994, and 2002, respectively. From 1992 to 1996, he worked as a teaching and research associate at UWM. From 1996 to 2001, he worked as a Senior Network Design Engineer in the cellular service provider industry. From 2001 to 2004, he worked as a Senior Research Engineer in the Advanced Technology Laboratory at Rockwell Automation HQ, Milwaukee, Wisconsin, USA. From 2004 to 2009, he worked as an assistant professor at the Department of Computer
Engineering at JUST. He is currently an assistant professor and a chairman at the Department of Network Engineering and Security at JUST. His research interests are in the area of wireless networking and robotics.

Omar Banimelhem received his $\mathrm{BSc}$ and $\mathrm{MSc}$ in Electrical Engineering from Jordan University of Science and Technology (JUST), Irbid, Jordan in 1995 and 1998 respectively. He received his $\mathrm{PhD}$ in Electrical and Computer Engineering from Concordia University, Montreal, Canada in 2006. From 2006 to 2009, he worked as an Assistant Professor at the department of Computer Engineering at JUST. Currently he is working as an Assistant Professor, Department of Network Engineering and Security, Irbid, JUST. His research interests focus on Computer Networks, Wireless Multimedia Sensor Networks and Artificial Intelligence Applications.

Eyad Taqieddin received his BSc in Electrical Engineering from Jordan University of Science and Technology (JUST) in 1999. He received his M.Sc. and Ph.D. in Computer Engineering from the University of Missouri-Rolla in 2002 and 2007, respectively. Currently, he is an Assistant Professor at the Department of Network Engineering and Security at JUST. His research interests include Wireless Multimedia Sensor Networks, Network Security, and Embedded Systems.

Raed Bani-Hani received his B.Sc. degree inElectrical and Computer Engineering from Jordan University of Science andTechnology, Jordan in 1999 and M.Sc. degree in Computer Science and ComputerEngineering from University of Missouri-Columbia, USA in 2003. Afterreceiving a Ph.D. degree in Electrical and Computer Engineering fromUniversity of Missouri-Columbia, USA in 2006, he joined the Department ofComputer Engineering, and then joined the Department of Network Engineering andSecurity (2009) as an assistant professor both at Jordan University ofScience and Technology. His research interests are network security, keymanagement, IPsec architecture, Wireless Sensor Networks with emphasis onsecure routing and location verification. 